\title{
THE TOPI HERD
}

\section{By Desmond Foster Vesey-FitzGerald, M.B.E., B.Sc.}

Although during these enlightened times the welfare of the wild life of $A$ frica is discussed internationally on a par with development, there is still great lack of information on the habits, ecological requirements and population densities of even the more common animals. This contribution attempts partly to fill this gap by recording the result of a years' observation on a herd of topi in the Rukwa valley of south-western Tanganyika.

The topi, Damaliscus korrigum jimela (Matschic), or tiang as it is called in some parts, is related to the hartebeests. It is more closely related to a group of less well known animals comprising Hunter's antelope, tsesscby, blesbok and bontebok, all of which have horns more curved and less angular than those of the true hartebeests. 'The blesbok and bontebok are virtually extinct as wild animals; the tsesseby has been shot out of much of its range, Hunter's antelope is found only in the dry north-east of Kenya and in Somaliland. The topi, which is widespread in castern and western Africa, is the commonest of them all. Though their horns do not make an exciting trophy, topi arc pretty beasts with dark brown coats and grey flank marks, which in some lights have an almost purple sheen. When they choose they are among the flectest of antelopes.

The IIabitat.-The Rukwa valley is bounded on the east and west by high escarpments and on the south, where the topi reaches the limit of its range, by the high land between lakes Nyasa and Tanganyika. To the north the Rukwa plains are bordered by open woods in which topi are seldom seen and which make at least a partial barricr. 'The three hundred square miles of open grass land at the north end of Lake Rukwa can thus be regarded as a faunal unit. These plains are virtually uninhabited by man and they have been proclaimed a controlled area, which at present amounts to giving the topi complete protection. 'The opportunity therefore arose of watching an isolated herd of topi under entirely natural conditions.

A Topi Census.-During the dry season much of the area is burnt and visibility across the plain good, in fact it is an ideal place to attempt a census of animals. The method employed was to make traverses in all directions and to count the topi which could be seen within a quarter of a mile of the traverse line. Thus a belt half a mile wide was covered-every two miles along the traverse giving a sample count of the topi population in one 
square mile. Twenty-one such traverses were made and the mean topi density found to be $\mathbf{2} \cdot \mathbf{3}$ per square mile. This gave a total population of 690 topi, but to this must be added the main herd which was excluded from the census and which was estimated at 1,200 .

It therefore seems that there are rather less than 2,000 topi in the $\mathbf{3 0 0}$ square miles of the Rukwa plains, that is seven to the square mile, or say ninety acres per head. This density seems very low and may be due either to predators, including man, or to ecological conditions. Lions, hunting dogs and hyænas are scarce; poachers used to be a scrious problem but in recent years their activities have been sharply curtailed. If shooting and poaching have been limiting factors to the topi population in the past, an increase in numbers should now be noticeable. Such an increase is in fact occurring.

Ecologically the area is peculiar. During half the year it may be extensively flooded; during the other half no fresh surface water may be available. The topi seem to have adapted themselves to these conditions by forming wet season concentrations away from the decply flooded places, while during the drought they scorn water holes which have been excavated for them, so long as they can find shoots of green grass sprouting after fires. During the last five years at any rate the topi have apparently not suffered any inconvenience from the droughts which have prevailed. 'The topi is an animal of short grass plains, although it will pass through long grass to get to its favoured grazing. Only about 100 square miles of this area can be classed as short grassland. So it may be that the real habitat of the topi is this smaller area. In this case the animals are occupying it at a density of about one animal to 32 acres, which, allowing for the presence of other game, compares not too unfavourably with the capacity of some other types of grassland in Africa.

The T'opi's Year.-The topi is essentially a gregarious animal, and in the Rukwa valley is found in parties of from a dozen or so to herds of several hundred strong. The topi's year starts during the rains in January when the main herd concentrates on the drier plains of shorter grass, which surround the flooded swamps of long grass in the bottom of the valley fringing the lake. It is not always easy to tell the males and females apart though the former are usually darker in colour. But the males collect on well marked stamping grounds where the grass is kept short by continual tramping, and where there is always a shallow rain water pool in which the animals love to splash about. 'These stamping grounds are the topi's real home where 
S.W. TANGANYIKA

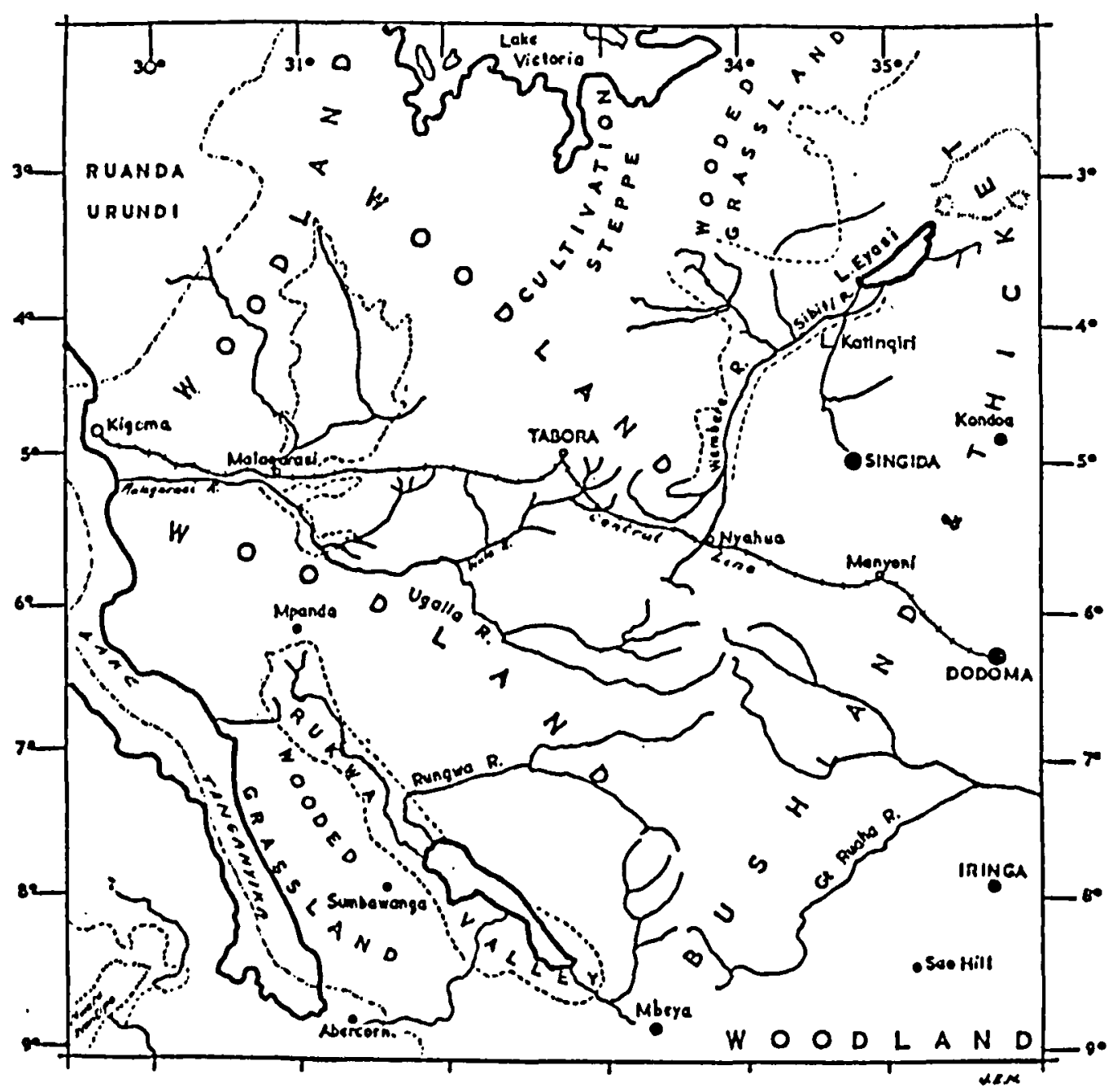

Miles

$20020 \times 60$ 10 100 2019000100200200
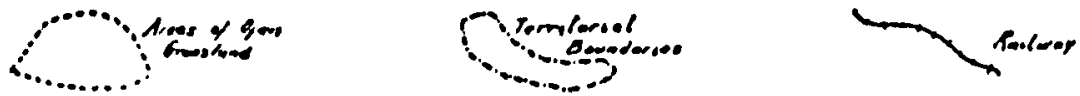

they delight to spend their time, chasing cach other with flaring nostrils and prancing gait, or indulging in horn to horn battles which sometimes become quite scrious affrays. Each male has his patch of ground trampled bare, a little castle he can call his own where he daily deposits his dung. Most of the chasing and mock battles secm to be connected with defending this little patch of sacred ground. 'The females and growing young meanwhile graze on the fresh young grasses around the fringes of the stamping ground where, when the rut is in full swing, mating takes place. $\Lambda$ stamping ground for a herd of a thousand or so may occupy one or two hundred acres. 
The rains finish in April and, as the floods recede and the grasses dry off, the topi herd leaves the stamping ground in search of fresh pastures. They feed only on grass and possibly the few herbs that grow among the grasses, but they never browse on the foliage of trees. They will trek long distances through the long grass to find the short grass lawns and burnt patches that they love. Even during the driest periods, the burnt grass-stools sprout fresh green shoots, within ten days or so of a fire. Fires may be started by lightning but are usually man-made, for the African's habit of burning the grass scems incurable. Nan's interference thus provides large areas of green pasture for the topi throughout the dry season. 'The animals also frequent the edge of the receding lake during the dry months where the wiry lake-shore grasses are nourished by the brackish water. Although topi do drink, they seem to be quite happy without water, as long as there is some green grazing.

During this period the herd splits up more and more into little parties, which wander far and wide over the plains, the males sceking solitude or the company of other game rather than their own kind.

The females secm to go about in parties in which the individuals are all in the same state of pregnancy. Newly born young have been seen as carly in the year as April but this is most exceptional. 'The main lambing time is towards the end of the dry senson in September. This is getting on towards the hottest time of the year and nlthough topi love the open plains, they now seck shade. Trees or even bushes, in the open grassland, are much frequented by the females with their young; for the woodland edge is a dangerous place if there are hunters or lions about. When danger threatens, the females bound away leaving the tiny lambs hidden in the grass. This ruse might work well, but the parent cannot bear to be parted from her young one. After going only a few yards, she comes bounding back again and the baby leaps up to meet her. 'The young are, however, unsteady on their legs for only a few hours; in a dny or two they are able to keep up wonderfully well with the swift pace of their parents.

Young topi are quite unlike their parents. They are a light reddish brown in colour and almost indistinguishable from the young of hartebecst. 'Twins are apparcntly unknown. Occasionally two or threc young are secn together but when there is an alarm cach runs to its own dam and "schools" of young never seem to be formed as hnppens with some other species such as clnnd. 
It is usual at this time of the year to see each female closely followed by her lamb wherever she goes. The young grow surprisingly fast; within three months their horns are already a few inches long, their baby coats are lost and the adult markings have appeared. Most of the young are half-grown by the end of the year when the males come back to the females and the great herd moves once again to its stamping ground. 